\section{LA ÚLTIMA GUERRA. \\ CULTURA VISUAL DE LA GUERRA \\ CONTRA PARAGUAY}

de Sebastián Díaz-Duhalde,

Buenos Aires, Sans Soleil, 2015, 266 pp.

EUGENIA PATRICIA ROSSI

Universidad Nacional de General Sarmiento (Argentina).
El I ${ }^{\circ}$ de mayo de 1865 , las dirigencias políticas del Brasil, Uruguay y Argentina concretaron una alianza cuyo principal objetivo fue el derrocamiento del gobernante de Paraguay, el mariscal Francisco Solano López. La Guerra de la Triple Alianza (I864-1870) constituye un episodio clave en la historia latinoamericana, en tanto redefinió el equilibrio político regional pero también porque su magnitud destructiva la ubica como una de las contiendas americanas más cruentas del siglo XIX.

Lejos ya de la historiografía decimonónica, interesada por las personalidades político-militares de renombre pero también tomando distancia de la corriente revisionista, el libro de Díaz-Duhalde se inscribe en un conjunto de miradas renovadas que entienden la guerra como un fenómeno político y económico pero también social y cultural en el marco de los procesos de formación de los Estados nacionales. A su vez, el autor recupera el planteamiento del historiador Luc Capdevila, quien estudió esta contienda desde sus ecos y persistencias en la memoria e imaginario de la sociedad paraguaya. En el prólogo del presente libro, Capdevila subraya el valioso aporte que Díaz-Duhalde hace a la reflexión sobre la cultura visual, las prácticas y los imaginarios puestos en juego por esta guerra.

La Guerra del Paraguay tuvo la particularidad de haber coincidido temporalmente con el surgimiento y difusión de nuevos medios de reproducción visual. El apogeo de la litografía en la prensa ilustrada y la novedad de la fotografía, en articulación con otros medios tradicionales como la pintura, estaban transformando los modos de ver y de representar la realidad. Por tal motivo, el libro propone una reflexión sobre las representaciones de este conflicto a partir de un conjunto de 
producciones visuales y textuales, tanto contemporáneas a la guerra como también posteriores a la misma. El autor examina cómo aquellas imágenes visibilizan la guerra, afrontan la violencia y en qué medida dan cuenta de la tragedia bélica.

Para pensar estas cuestiones, el libro dispone de dos partes, integradas por dos capítulos cada una. La primera de ellas, Guerra, imágenes y textos, se dedica a estudiar tres casos de representaciones elaboradas durante el desarrollo del conflicto y en su inmediatez, durante el siglo XIX: las pinturas del soldado argentino Cándido López, las fotografías del estudio uruguayo Bate \& Cía. y el diario de guerra del coronel uruguayo León de Palleja. Esta sección enfatiza la dialéctica entre el registro visual y el escrito. La segunda parte, Un archivo de la guerra, explora algunas de las producciones que, entre fines del siglo XIX y el siglo xxI reorganizaron y reinterpretaron aquellas imágenes de la guerra: el documental Cándido López, los campos de batalla (2005) del argentino José Luis García; el Álbum de la Guerra del Paraguay (1893-1896) de la Asociación de Guerreros del Paraguay (Argentina); La Guerra del 70. Una visión fotográfica (1985) publicada por el Museo del Barro (Paraguay) y Soldados de la memoria. Imágenes y hombres de la Guerra del Paraguay (2000) del argentino Miguel Ángel Cuarterolo.

En el primer capítulo se analiza cómo aparece la guerra en las pinturas de
Cándido López y la importancia concedida al entorno natural y a la vida cotidiana de la multitud de minúsculos y anónimos soldados. Distanciándose de los cánones pictóricos de su época, estas composiciones no ofrecen una glorificación de la contienda o una épica nacional, sino que, como señala el autor, exponen la «labor de la guerra». En particular, Díaz-Duhalde se interesa por la serie de obras llamativamente dedicada a la derrota aliada en la Batalla de Curupaytí. En ella, este soldado-cronista intenta dar accesibilidad a este episodio en una suerte de visión total, mediante nueve pinturas que plasman distintos momentos de la batalla, incluso desde la perspectiva paraguaya. En este análisis, Díaz-Duhalde incorpora también los escritos de López que acompañan sus óleos. Se trata de comentarios de su autoría referidos a las condiciones y contexto de producción de sus obras, a sus vivencias personales de la guerra pero también dialogan con documentos, crónicas y testimonios de otros autores de la época. Por tanto, aquí se aborda la composición mixta de López, en la que imagen y texto se articulan en una unidad narrativa y una nueva visibilidad de la guerra y en la que el autor advierte una "épica negativa».

El segundo capítulo se detiene a analizar las fotografías tomadas por el estudio uruguayo Bate \& Cía. y el Diario de la campaña de las Fuerzas Aliadas contra El Paraguay 
(I865-I866) del coronel León de Palleja. La producción fotográfica de esta conflagración, la primera en ser fotografiada en Sudamérica, puede clasificarse en fotos de estudio y del frente de batalla. Del primer grupo, se examina principalmente las del formato carte de visite. Díaz-Duhalde repasa los pormenores de las técnicas y la implementación de la fotografía durante la contienda como, así también, los modos de circulación de estas imágenes. El autor señala que estas fotografías se caracterizan por no exhibir, de hecho, ningún combate físico sino más bien las huellas o el producto de la lucha, rasgo vinculado a las propias dificultades que presentaba el proceso fotográfico de aquél entonces. Asimismo, otro rasgo al que apunta el autor es la ausencia de epígrafes o narraciones que adjudicaran una historia a estas imágenes. En su Diario, León de Palleja narra su día a día al mando del batallón Florida hasta su deceso en la Batalla de Boquerón del Sauce (I8 de julio de I866). El libro explora los diversos registros y matices de esta narración, advirtiendo pasajes de tono crítico ante la guerra junto con cierta influencia de la visualidad fotográfica en la utilización del lenguaje.

El capítulo tercero ofrece una mirada crítica del documental Cándido López. Los campos de batalla. Dos ejes parecen guiar este film: el encuentro de López como sujeto para aproximarse a la guerra desde el presente y la búsqueda de un pasado que configure y otorgue sentido la realidad de los vecinos de los campos de batalla que ofrecen su testimonio en el documental. En ese pasado, el fenómeno bélico es presentado como un suceso impreciso que no cuestiona la visión historiográfica tradicional sobre el conflicto. Asimismo, a juicio del autor, se percibe que los trabajos del pintor se muestran disociados de su carácter de producto artístico y no se discute el supuesto valor testimonial de estos óleos ejecutados casi dos décadas después de finalizada la contienda. Esta presunción lleva al director a buscar permanentemente las coincidencias de lo que se encuentra en su viaje con lo que se exhibe en las pinturas, dando pie a lo que Díaz-Duhalde califica como una yuxtaposición temporal.

En el cuarto capítulo, el autor reflexiona en torno a la existencia material de la fotografía y los modos en que estas imágenes de la guerra fueron seleccionadas, reorganizadas y resignificadas a través de distintas colecciones. En primer lugar, se examina el Álbum de la Guerra del Paraguay (1893-1896) destacando la heterogeneidad de materiales incluidos en sus páginas. En ellas, se reúnen testimonios de veteranos de guerra, notas de opinión y diversas anécdotas, acompañadas de ilustraciones, fotografías y retratos de los participantes, tanto célebres como desconocidos. El álbum signado por el filtro del acervo privado de los familiares de los soldados se 
aparta de la lógica de las glorias militares e incluye imágenes sin relación al contenido del texto. Para Díaz-Duhalde, se trata de una publicación novedosa que rompe con las formas tradicionales de "contar» la guerra, en tanto plantea una nueva articulación entre lo visible y lo legible. $L a$ Guerra del 70. Una visión fotográfica, reproduce treinta fotografías de la casa Bate y Cía., pertenecientes a la colección de la Biblioteca Nacional del Uruguay junto a once fotos anónimas, fechadas en 1908. Duhalde resalta la idea de los autores del álbum de la materialidad de la fotografía como documento histórico, en tanto captura fragmentos de aquella realidad bélica y también su preocupación por respetar la disposición y características originales de las imágenes. Asimismo, examina un excedente de II fotos posteriores al conflicto que exhiben paisajes en donde se supone que la guerra ocurrió. Vinculando estas imágenes con la idea de «fósil», Díaz-Duhalde reflexiona sobre cómo las fotografías dialogan con la actualidad paraguaya de 1985 , año en que fue editada esta publicación.

Respecto de Soldados de la memoria, se indica que esta colección aborda las imágenes de la guerra repasando la historia de la fotografía e integrándola en un contexto histórico en el que circulaban otro tipo de registros visuales. De esta manera, al poner en diálogo la fotografía con otros discursos, se destaca la labor de Cuarterolo, quien supo anticiparse, de algún modo, a las tendencias actuales de los estudios de la cultura visual. En adición, el autor se detiene a reflexionar en torno a la dimensión material de la fotografía que plantea esta colección al explicitar el proceso de digitalización al que fueron sometidas las imágenes. Esta explicitación, a su vez, remite a la cuestión de la corrupción de dicha materialidad a causa del paso del tiempo. El libro finaliza con una coda que indaga los retratos en las representaciones de esta guerra. En particular, se hace foco en las numerosas imágenes del mariscal Solano López, cuyo rostro, a diferencia de los del resto de los líderes participantes, no sufrió un tratamiento caricaturesco. En síntesis, este libro propone una aproximación a la Guerra de la Triple Alianza en torno a estos cuatro episodios visuales a través de una mirada interdisciplinaria sobre los modos en que la guerra fue vista y mostrada y cómo esas visiones fragmentarias de la violencia bélica fueron asumidas y resignificadas. 